\title{
PENGETAHUAN IBU TENTANG IMUNISASI DASAR DI POSYANDU
}

\author{
Veti Febri Aditiyani*) \\ * Sekolah Tinggi IImu Kesehatan Prima Indonesia \\ Jurusan Diploma Tiga Kebidanan \\ Email : veti@stikesprimaindonesia.ac.id
}

\begin{abstract}
Background:The immunization program is one of the programs of the health department in the field of disease prevention by providing protection within the child's body, in this connection related to health problems caused by immunization preventable diseases, among others: Tuberculosis, diphtheria, tetanus, whooping cough, polio , measles, mumps, hepatitis and maningitis. The immunization program was carried out by the government since 1977 and has developed until now (Markum, 1997). The target of determining the program determined by Bekasi Regency in the sixth round is that $80 \%$ of all babies must get complete immunization with the following details: BCG $90 \%$, DPT 90\%, Polio 90\%, Measles $80 \%$ Hepatitis B $80 \%$.

Purpose:To describe the level of knowledge of mothers about basic immunization at the Posyandu RW.06 Karang Asih Village, North Cikarang District, Bekasi, July 2005.

Methods: The design of this study was descriptive with a cross section design which aims to get an overview of the level of knowledge of mothers about basic immunization seen from the factors of education, employment and information sources. The time of the study was conducted in June - August 2005. Population of 132 people and a total sample of 70 people. How to take samples by simple random sampling. Univariate data analysis. The data collection tool in this study was using questionnaires and interviews.

Result:The level of knowledge about basic immunization with sufficient categories was 38 (54.3\%) respondents. The education level of mothers about basic immunization with a low education category was 47 $(67.2 \%)$ respondents. There were $42(60 \%)$ respondents of non-working mothers. Sources of information about basic immunization were seen from health workers as many as 44 (62.8\%) respondents

Conclusion: From the research results obtained a level of knowledge about basic immunization with a category of enough 38 (54.8\%) Respondents. The education level of a low-educated mother 47 (67.2\%) Respondents. From the job factor, the mother who did not work as much as 42 (60\%) Respondents. The most information source from healthcare personnel as much as 44 (62.8\%) Respondents
\end{abstract}

Key Word : Imunization,Knowlegde,mother

\section{ABSTRAK}

Latar Belakang: Program imunisasi merupakan salah satu program dari departemen kesehatan di bidang pencegahan penyakit dengan memberikan kekebalan di dalam tubuh anak, dalam hubungan ini diketahui bahwa masalah kesehatan yang ditimbulkan oleh penyakit yang dapat dicegah dengan imunisasi antara lain : Tuberculosis, difteri, tetanus, batuk rejan, polio, campak, gondong, hepatitis dan maningitis. Angka kematian bayi di Jawa Barat Kebupaten Bekasi pada tahun 2001 sebanyak 63 per 1000 kelahiran hidup, tahun 2003 AKB 62 per 1000 kelahiran hidup, sedangkan tahun 2005 terjadi penurunan yaitu 40 per 1000 kelahiran hidup (Gisianturi, 2005).Program imunisasi tersebut dilaksanakan pemerintah sejak tahun 1977 dan berkembang sampai sekarang (Markum, 1997). Target pencapaian program yang ditentukan Kabupaten Bekasi pada pelita VI adalah $80 \%$ dari semua bayi harus mendapatkan imunisasi lengkap dengan perincian target sebagai berikut : BCG $90 \%$, DPT 90\%, Polio 90\%, Campak $80 \%$ Hepatitis B $80 \%$.

Tujuan: Untuk mengetahui gambaran tingkat pengetahuan ibu tentang imunisasi dasar di Posyandu RW.06 Desa Karang Asih Kecamatan Cikarang Utara Bekasi Juli 2005. 
Metode: Rancangan penelitian ini adalah bersifat deskriptif dengan desain cross sectional yang bertujuan untuk mendapatkan gambaran tingkat pengetahuan ibu tentang imunisasi dasar dilihat dari faktor pendidikan, pekerjaan dan sumber informasi. Waktu penelitian telah dilaksanakan pada bulan Juni - Agustus 2005. Dengan jumlah populasi 132 orang dan jumlah sampel sebanyak 70 orang. Cara pengambilan sampel dengan simple random sampling. Analisis data secara univariat. Alat pengumpulan data pada penelitian ini adalah dengan menggunakan kuesioner dan wawancara.

Hasil: Tingkat pengetahuan tentang imunisasi dasar dengan kategori cukup sebanyak 38 (54,3\%) responden. Tingkat pendidikan ibu tentang imunisasi dasar dengan kategori pendidikan rendah sebanyak 47 $(67,2 \%)$ responden. Kategori ibu tidak bekerja sebanyak $42(60 \%)$ responden. Sumber informasi tentang imunisasi dasar dilihat dari tenaga kesehatan sebanyak $44(62,8 \%)$ responden.

Kesimpulan: Dari hasil penelitian diperoleh tingkat pengetahuan tentang imunisasi dasar dengan kategori cukup $38(54,8 \%)$ Responden. Tingkat pendidikan ibu berpendidikan rendah $47(67,2 \%)$ Responden. Dari faktor pekerjaan, ibu yang tidak bekerja sebanyak $42(60 \%)$ responden. Sumber informasi terbanyak dari tenaga kesehatan sebanyak 44 (62,8\%) Responden

Kata Kunci: Imunisasi, pengetahuan, lbu

\section{PENDAHULUAN}

Angka Kematian Bayi (AKB) merupakan salah satu masalah yang paling utama untuk menggambarkan derajat kesehatan masyarakat dan juga merupakan ukuran penting dalam menilai keberhasilan pelayanan kesehatan dalam suatu negara. Menurut WHO pada tahun 1992 imunisasi dapat mencegah 2,9 juta kematian karena campak, tetanus dan pertusis. Angka kematian bayi di dunia pada tahun 2003 yaitu 117 per 1000 kelahiran hidup (Dadang, 2003). Di Negara sedang berkembang diperkirakan dalam 1000 campak kematian bayi dan balita sering ditimbulkan akibat kekurangan gizi, pnemonia, diare terjadi pada 25 juta kasus dari 72 juta kasus (Depkes RI, 1999).

Di Indonesia angka kematian bayi relatif tinggi bila dibandingkan dengan Negara - Negara ASEAN dimana posisi Indonesia masih menempati urutan keenam. Perkembangan angka kematian bayi dalam beberapa tahun terakhir ini antara lain : pada tahun 1994 AKB 56 per 1000 kelahiran hidup (Risto, 1994), tahun 1995 AKB 51 per 1000 kelahiran hidup (Supas, 1995), tahun 1997 AKB 46 per 1000 kelahiran hidup, tahun 2001 AKB 50 per 1000 kelahiran hidup (Susenas, 2001), sedangkan tahun 2003 terjadi penurunan yaitu 35 per 1000 kelahiran hidup (Sumaryati, 2003).

Angka kematian bayi di Jawa Barat Kebupaten Bekasi pada tahun 2001 sebanyak 63 per 1000 kelahiran hidup, tahun 2003 AKB 62 per 1000 kelahiran hidup, sedangkan tahun 2005 terjadi penurunan yaitu 40 per 1000 kelahiran hidup (Gisianturi, 2005).

Dua penyebab kematian bayi dan balita yang menonjol adalah penyakit infeksi yang sebagian dapat dicegah dengan imunisasi dan penyakit non imunisasi (Markum, 1997).

Program imunisasi merupakan salah satu program dari departemen kesehatan di bidang pencegahan penyakit dengan memberikan kekebalan di dalam tubuh anak, dalam hubungan ini diketahui bahwa masalah kesehatan yang ditimbulkan oleh penyakit yang dapat dicegah dengan imunisasi antara lain : Tuberculosis, difteri, tetanus, batuk rejan, polio, campak, gondong, hepatitis dan maningitis. Program imunisasi tersebut dilaksanakan pemerintah sejak tahun 1977 dan berkembang sampai sekarang (Markum, 1997).

Oleh pemerintah program imunisasi dianggap sebagai salah satu intervensi kesehatan yang sangat berhasil guna untuk menurunkan angka kesakitan, kematian dan kecacatan bayi dan balita yang dapat ditimbulkan oleh penyakit yang dapat dicegah dengan imunisasi. Dalam program imunisasi tersebut pemerintah menerapkan tercapainya Universal Chil Imunizatioan (UCI) di Indonesia. Sehingga upaya untuk menurunkan angka kesakitan, kematian dan kecacatan bayi dan balita serta upaya untuk mencapai derajat kesehatan dapat segara terwujud (Depkes RI, 1997).

Pada tahun 1984 cakupan lengkap secara nasional, Indonesia baru mencapai sekitar 4\% dengan adanya bantuan donor internasional (WHO, 
UNICEF, USAID) dilakukan program imunisasi nasional yang berupa mendistribusikan seluruh kebutuhan vaksin dan peralatan rantai dinginnya serta melatih tenaga vaksinator dan pengelola rantai dingin. Pada akhir tahun 1989 sejumlah 96\% dari semua kecamatan di Indonesia telah dapat memberikan pelayanan imunisasi secara teratur. Dengan strategi tersebut pada akhir tahun 1990 yaitu lebih dari $80 \%$ bayi di Indonesia mendapat imunisasi dasar lengkap sebelum ulang tahunnya yang pertama. Pencapaian $\mathrm{UCl}$ di tingkat nasional tersebut hendak dicapai pula untuk setiap propinsi, setiap kabupaten, setiap kecamatan dan akhirnya disetiap desa pada tahun 2000 (Markum, 1997).

Indikator yang menjadi tolak ukur keberhasilan program imunisasi bayi yaitu indikator cakupan. Target pencapaian program yang ditentukan pada akhir pelita VI adalah minimal $80 \%$ dari semua bayi yang harus mendapatkan imunisasi lengkap dengan perincian target nasional sebagai indikator UCl tahun 1997 : BCG 90\%, DPT 90\%, Polio $80 \%$, Campak $80 \%$, Bepatitis B $80 \%$.

Data dokumentasi hasil cakupan imunisasi bayi di Posyandu RW 06 Desa Karang Asih Kecamatan Cikarang Utara Bekasi tahun 2004 adalah sebagai berikut : diperoleh jumlah bayi sebanyakt 132 orang, dengan hasil cakupan yang didapat yang mengikuti program imunisasi seluruhnya adalah : BCG 56 , DPT 82 , Polio 82 , Campak 58, Hepatitis B 82.

Pengetahuan merupakan faktor presposisi yang mendasari seseorang untuk berperilaku didalam pengetahuan tercakup pemikiran proses tentang kepercayaan tradisi yang berlaku, pada ibu ibu yang membawa anaknya untuk diimunisasi mempunyai nilai positif baik dipandang dari sudut kesehatan, ekonomi atau psikologi. Faktor - faktor yang mempengaruhi tingkat pengetahuan ibu tentang imunisasi dasar yaitu faktor pendidikan, pekerjaan, sumber informasi, sosial budaya, motivasi (Green dalam Husnawaty, 2003).

Berdasarkan penelitian terdahulu Husnawaty, 2003 yang berjudul "Karakteristik Pengetahuan dan Motivasi Ibu terhadap Imunisasi Dasar di Posyandu RW.08 Desa Karang Anyar Kecamatan Legok Tanggerang" didapatkan cakupan imunisasinya $82 \%$ dan tingkat pengetahuan ibu tentang imunisasi cukup baik sebanyak $73 \%$. Maka peneliti tertarik untuk meneliti "Gambaran Tingkat Pengetahuan Ibu tentang Imunisasi Dasar di Posyandu Rw.06 Desa Karang Asih Kecamatan Cikarang Utara Bekasi Juli 2005".

\section{METODOLOGI PENELITIAN}

Rancangan penelitian ini adalah bersifat deskriptif dengan desain cross section yang bertujuan untuk mendapatkan gambaran tingkat pengetahuan ibu tentang imunisasi dasar dilihat dari faktor pendidikan, pekerjaan dan sumber informasi.Populasi sebanyak132 orang dan sampel sebanyak 70 orang dengan tekhnik pengambilan sampel secara simple random sampling. Analisis data secara univariat. Alat pengumpulan data pada penelitian ini adalah dengan menggunakan kuesioner dan wawancara.

Waktu penelitian telah dilaksanakan pada bulan Juni - Agustus 2005. Alat pengumpulan data pada penelitian ini adalah dengan menggunakan kuesioner dan wawancara.

\section{HASIL DAN PEMBAHASAN}

Tabel 1 Distribusi Frekuensi Tingkat Pengetahuan Ibu tentang Imunisasi Dasar

\begin{tabular}{ccc}
\hline Pengetahuan & Frekuensi & $\%$ \\
\hline Baik & 24 & 34,3 \\
Cukup & 38 & 54,3 \\
Kurang & 8 & 11,4 \\
Total & 70 & 100 \\
\hline
\end{tabular}

Berdasarkan tabel diatas dapat dilihat dari 70 responden dengan tingkat pengetahuan baik sebanyak $24(34,3 \%)$ responden, tingkat pengetahuan cukup sebanyak 38 (54,3\%) responden dan tingkat pengetahuan kurang sebanyak $8(11,4 \%)$ responden. 
Tabel 2 Distribusi Frekuensi Tingkat Pendidikan

\begin{tabular}{ccc}
\hline Pendidikan & Frekuensi & $\%$ \\
\hline $\begin{array}{c}\text { Tingkat Pendidikan Tinggi } \\
\text { (SMA dan Perguruan Tinggi) } \\
\text { Tingkat Pendidikan Rendah } \\
\text { (SMP dan SD) }\end{array}$ & 23 & 32,8 \\
\hline Total & 47 & 67,2 \\
\hline
\end{tabular}

Berdasarkan tabel diatas dapat dilihat dari 70 responden dengan tingkat pendidikan tinggi sebanyak $23(32,8 \%)$ responden, tingkat pendidikan rendah sebanyak $47(67,2 \%)$ responden.

Tabel 3 Distribusi Frekuensi Faktor Pekerjaan

\begin{tabular}{ccc}
\hline Pekerjaan & Frekuensi & $\%$ \\
\hline Bekerja & 28 & 40 \\
Tidak Bekerja & 42 & 60 \\
\hline Total & 70 & 100 \\
\hline
\end{tabular}

Berdasarkan tabel diatas dapat dilihat dari 70 responden dengan kategori bekerja sebanyak 28
$(40 \%)$ responden, kategori tidak bekerja sebanyak $42(60 \%)$ responden.

Tabel 4 Distribusi Frekuensi Sumber Informasi

\begin{tabular}{ccc}
\hline Sumber Informasi & Frekuensi & $\%$ \\
\hline Tenaga Kesehatan & 44 & 62,8 \\
Media Massa & 26 & 37,2 \\
\hline Total & 70 & 100 \\
\hline
\end{tabular}

Berdasarkan tabel diatas sumber informasi dari tenaga kesehatan sebanyak $44 \quad(62,8 \%)$ responden, sumber informasi dari media massa sebanyak $26(37,2 \%)$ responden.

\section{PEMBAHASAN}

Berdasarkan tabel 1 dapat diketahui bahwa pengetahuan ibu tentang imunisasi dasar adalah tingkat pengetahuannya sudah cukup baik sebanyak $38(54,3 \%)$ responden, menurut penelitian hal ini disebabkan karena adanya posyandu di Rw. 06 yag sudah berjalan aktif sejak tahun 2003, dimana setiap 1 bulan sekali bidan memberikan penyuluhan tentang imunisasi dasar. Hal ini didukung dengan teori Green (1980) dalam Husnawaty (2003), menyatakan bahwa pengetahuan merupakan faktor predisposisi yang mendasari seseorang untuk berperilaku didalam pengetahuan tercakup pemikiran proses tentang kepercayaan tradisi yang berlaku, pada ibu - ibu yang membawa anak anaknya untuk di imunisasi pengetahuan tentang manfaat dari imunisasi mempunyai nilai positif baik dari sudut pandang kesehatan, ekonomi atau psikologi.

Berdasarkan tabel 2 dapat diketahui bahwa tingkat pengetahuan ibu tentang imunisasi dasar dilihat dari faktor pendidikan ibu sebagian besar tingkat pendidikan ibu adalah pendidikan rendah sebanyak $47(67,2 \%)$ menurut peneliti hal ini disebabkan karena di Posyandu Rw. 06 sosial ekonominya rendah dimana rata - rata pencaharian orang tuanya buruh tidak tetap sehingga menyebabkan ibu tidak dapat melanjutkan tingkat pendidikan ke jenjang yang lebih tinggi, walaupun pendidikan ibu rendah tingkat pengetahuan ibu tentang imunisasi dasar sudah cukup baik dan ibu tetap memperhatikan kesehatan anaknya dengan cara membawa anaknya ke Posyandu untuk diimunisasi dan mencari informasi tentang manfaat imunisasi.

Berdasarkan tabel 3 dapat diketahui bahwa tingkat pengetahuan ibu tentang imunisasi dasar 
dilihat dari faktor pekerjaan ibu sebagaian besar adalah tidak bekerja $42(60 \%)$ responden. Menurut peneliti hal ini disebabkan karena pendidikan ibu rendah maka terbatasnya lapangan pekerjaan bagi ibu. Hal ini didukung dengan teori Muhibbin (1999) dalam Husnawaty (2003) dimaksud dengan pekerjaan bila ibu beraktifitas keluar rumah ataupun didlam rumah untuk mendapatkan uang kecuali pekerjaan rutin ibu rumah tangga.

Berdasarka tabel 4 dapat diketahui tingkat pengetahuan ibu tentang imunisasi dasar dilihat dari faktor sumber informasi tertinggi adalah tenaga kesehatan sebanyak $44(62,8 \%)$. hal ini didukung dengan teori Djuanto (1996) dalam Husnawaty (2003) menyatakan informasi tentang imunisasi bila didapatka pasca lahir dapat berpengaruh terhadap ibu dalam tingkat pengetahuan tentang imunisasi, peran keluarga sebagai reuforcing social support dan referensi menjadi masukan yang terpenting untuk menentukan dalam perilaku seseorang selain keluarga media informasi seperti petugas kesehatan dan media massa seperti media cetak (koran dan majalah) dan media elektronik (TV dan radio).

\section{SIMPULAN}

Tingkat pengetahuan tentang imunisasi dasar dengan kategori cukup sebanyak 38 (54,3\%) responden. Tingkat pendidikan ibu tentang imunisasi dasar dengan kategori pendidikan rendah sebanyak $47(67,2 \%)$ responden. Kategori ibu tidak bekerja sebanyak $42(60 \%)$ responden. Sumber informasi tentang imunisasi dasar dilihat dari tenaga kesehatan sebanyak $44(62,8 \%)$ responden.

\section{SARAN}

Kader Posyandu diharapkan dapat memberikan motivasi ibu yang memiliki bayi untuk melakukan imunisasi dasar. Tenaga kesehatan diharapkan untuk meningkatkan penyuluhan tentang pentingnya imunisasi dasar, tidak hanya dilakukaan saat kegiatan posyandu. Keluarga diharapkan dapat memotivasi dan sadar akan pentingnya imunisasi untuk anaknya.

\section{DAFTAR PUSTAKA}

Abednego, H, 1996, Petunjuk Teknis Reaksi Samping Imunisasi, Depkes RI, Jakarta.

A.H. Markum, 1997, Imunisasi, Edisi II, FKUI, Jakarta.

Depkes RI, 1999, Rencana Pembangunan Kesehatan Menuju Indonesia Sehat 2010, Depkes RI, Jakarta.

Dick, George, 1995, Imunisasi Dalam Praktek, Hipokrates, Jakarta.

Gisianturi (17 Juni 2005), Angka Kematian Bayi Di Jawa BArat MAsih Tinggi, Bekasi.

Husnawaty, 2003, Karakteristik Tingkat Pengetahuan Dan Motivasi Ibu Terhadap Imunisasi Skripsi Fakultas Kesehatan Universitas Indonesia, Jakarta.

Mulyani N., 2004, Faktor - Faktor Yang Berhubungan Dengan Perilaku Ibu Terhadap Pelaksanaan Imunisasi Fakultas Imunisasi Skripsi Fakultas Kesehatan Masyarakat, Universitas Respati Indonesia, Jakarta.

Notoatmojo, Soekidjo, 2002, Metodologi Penelitian Kesehatan Edisi II, Aneka Cipta, Jakarta.

Sitorus R., 1996, Pedoman Kesehatan Dan Perawatan Anak, Pionir Jaya, Bandung.

Saltati, C, 1997, Perilaku, Akademi Perawatan Sint Carolus, Jakarta.

Sumaryati (19 Desember 2003), Survey Demografi Dan Kesehatan Anak Indonesia, Jakarta.

Wardhana, 2001, Pengaruh Pengetahuan Ibu Tentang Imunisasi Skripsi Fakultas Kesehatan Masyarakat, Universitas Indonesia, 2001. 